\title{
ANTESEDEN KUALITAS LAPORAN KEUANGAN PEMERINTAH DAERAH
}

Tri Haryati

Kantor Wilayah Ditjen Perbendaharaan Provinsi Jawa Tengah

Alamat Korespondensi: tri.haryati@kemenkeu.go.id

\section{INFORMASI ARTIKEL}

Diterima Pertama

13 Juni 2016

Dinyatakan Diterima

14 November 2016

\section{KATA KUNCI:}

Quality of Local Government Financial Reports, Commitment of Management, Human Resources Competencies, Effectiveness of the Internal Auditor, Quality of Accounting System, Follow-Up of Audit Findings.

KLASIFIKASI JEL:

H83.

\begin{abstract}
ABSTRAK
This study investigates factors in the quality of local government financial reports, extending a previous study using five exogenous variables, namely commitment of management, human resources competencies, effectiveness of the internal auditor, quality of accounting system and the follow-up of audit findings from the Supreme Auditor (BPK). The research data population comprised 50 Spending Units in the area of Semarang local government. The data was collected by distributing questionnaires to all Spending Units, of whom 49 responded to questionnaires within the prescribed time. Partial Least Square (PLS) technique was used to analyze data processed using Smart PLS 3.0. The results show that the quality of the accounting system and follow-up the audit findings from the BPK have positive and significant impacts on the quality of local government financial reports. Other variables such as the commitment of management, human resources competencies and effectiveness of the internal auditor do not significantly affect the quality of local government financial reports.
\end{abstract}

Penelitian ini bertujuan untuk menganalisis faktor-faktor yang mempengaruhi kualitas laporan keuangan pemerintah daerah. Penelitian ini merupakan pengembangan dari penelitian sebelumnya dengan menggunakan lima variabel eksogen yaitu komitmen manajemen, kompetensi sumber daya manusia, efektivitas auditor internal, kualitas sistem akuntansi dan penyelesaian tindak lanjut temuan BPK. Populasi penelitian berjumlah 50 yang merupakan Satuan Kerja Perangkat Daerah pada pemerintah Kota Semarang. Pengambilan sampel dilakukan dengan menyebarkan kuesioner kepada seluruh satuan kerja perangkat daerah. Jumlah sampel yang terkumpul setelah batas waktu yang ditentukan sebanyak 49 responden. Teknik analisis yang digunakan adalah Partial Least Square (PLS) dan pengolahan data dengan menggunakan alat bantu Smart PLS 3.0. Hasil penelitian menunjukkan bahwa kualitas sistem akuntansi dan penyelesaian tindak lanjut temuan BPK berpengaruh positif dan signifikan terhadap kualitas laporan keuangan pemerintah daerah. Sedangkan variabel lain meliputi komitmen manajemen, kompetensi sumber daya manusia dan efektivitas auditor internal tidak signifikan mempengaruhi kualitas laporan keuangan pemerintah daerah. 


\section{PENDAHULUAN}

\subsection{Latar Belakang}

Undang-Undang

Keuangan Negara menyebutkan bahwa salah satu upaya konkrit untuk mewujudkan transparansi dan akuntabilitas pengelolaan keuangan negara adalah penyampaian laporan pertanggungjawaban keuangan pemerintah yang memenuhi prinsip tepat waktu dan disusun sesuai standar akuntansi pemerintahan. Berdasarkan undang-undang ini pemerintah wajib menyusun laporan keuangan sebagai bentuk pertanggungjawaban atas pelaksanaan Anggaran Pendapatan dan Belanja Negara (APBN) dan/ atau Anggaran Pendapatan dan Belanja Daerah (APBD).

Undang-Undang Perbendaharaan Negara menyatakan bahwa laporan keuangan pemerintah dihasilkan melalui proses akuntansi. Laporan keuangan disampaikan kepada Dewan Perwakilan Rakyat/ Dewan Perwakilan Rakyat Daerah (DPR/DPRD) selambat-lambatnya 6 (enam) bulan setelah tahun anggaran yang bersangkutan berakhir setelah terlebih dahulu diperiksa oleh Badan Pemeriksa Keuangan (BPK). Pelaksanaan audit merupakan sesuatu hal yang penting dalam rangka memberikan keyakinan bahwa laporan pertanggungjawaban yang menyangkut aspek keuangan dan operasional, kredibilitasnya dapat dipertanggungjawabkan.

Hasil pemeriksaan atas Laporan Keuangan Pemerintah Daerah (LKPD) berupa pendapat/ opini. Opini merupakan pernyataan profesional pemeriksa mengenai kewajaran informasi keuangan yang disajikan dalam laporan keuangan yang didasarkan pada, (a) kesesuaian dengan standar akuntansi pemerintahan; (b) kecukupan pengungkapan (adequate disclosure); (c) kepatuhan terhadap peraturan perundangundangan; dan (d) efektivitas Sistem Pengendalian Intern (SPI). Terdapat 4 (empat) jenis opini yang dapat diberikan oleh BPK, yaitu: (i) opini wajar tanpa pengecualian (unqualified opinion), (ii) opini wajar dengan pengecualian (qualified opinion), (iii) opini tidak wajar (adversed opinion), dan (iv) pernyataan menolak memberikan opini (disclaimer of opinion).

Penyajian suatu laporan keuangan yang wajar merupakan gambaran dan hasil dari pengelolaan keuangan yang lebih baik. Hasil audit BPK atas LKPD menunjukkan kualitas laporan keuangan tersebut. Namun demikian opini BPK terhadap LKPD, masih belum mencerminkan kondisi yang ideal. Publikasi BPK, Ikhtisar Hasil Pemeriksaan Semester (IHPS) I dan II tahun 2014, sampai dengan LKPD tahun 2013 jumlah pemerintah daerah yang mendapatkan opini Wajar Tanpa Pengecualian baru 156 (30\%) dari 524 pemerintah daerah provinsi/ kabupaten/ kota yang wajib menyusun laporan keuangan tahun 2013. Tabel di bawah ini menyajikan perkembangan opini LKPD tahun 2009 sampai dengan 2013.

Tabel 1. Perkembangan Opini LKPD Tahun 2009 s.d. 2013

\begin{tabular}{|c|c|c|c|c|c|c|c|c|c|}
\multirow{2}{*}{$\begin{array}{c}\text { LKPD } \\
\text { (Tahun) }\end{array}$} & \multicolumn{7}{|c|}{ OPINI } & \multirow{2}{*}{ JUMLAH } \\
\cline { 2 - 10 } & WTP & $\%$ & WDP & $\%$ & TW & $\%$ & TMP & $\%$ & \\
\hline 2009 & 15 & 3 & 330 & 65 & 48 & 10 & 111 & 22 & 504 \\
\hline 2010 & 34 & 7 & 341 & 65 & 26 & 5 & 121 & 23 & 522 \\
\hline 2011 & 67 & 13 & 349 & 67 & 8 & 1 & 100 & 19 & 524 \\
\hline 2012 & 120 & 23 & 319 & 61 & 6 & 1 & 79 & 15 & 524 \\
\hline 2013 & 156 & 30 & 311 & 59 & 11 & 2 & 46 & 4 & 524 \\
\hline
\end{tabular}

Sumber: www.bpk.go.id-IHPS II Tahun 2014

Hasil evaluasi BPK dalam Ikhtisar Hasil Pemeriksaan Semester (IHPS) I dan II tahun 2014 menyatakan bahwa kasus-kasus kelemahan Sistem Pengendalian Internal (SPI) sebagai salah satu faktor penyebab belum memperoleh opini WTP, pada umumnya terjadi karena: pejabat/ pelaksana yang bertanggung jawab lalai dan tidak cermat dalam menyajikan laporan keuangan, belum optimal dalam melaksanakan tugas dan tanggung jawabnya sesuai tupoksi masing-masing, belum sepenuhnya memahami ketentuan yang berlaku, lemah dalam melakukan pengawasan dan pengendalian kegiatan, kurangnya koordinasi dengan pihak-pihak terkait, serta kelemahan pada sistem aplikasi yang digunakan. Selain itu, kasus kelemahan SPI juga terjadi karena pejabat yang berwenang belum menyusun dan menetapkan kebijakan yang formal untuk suatu prosedur atau keseluruhan prosedur, kurang cermat dalam melakukan perencanaan dan pelaksanaan kegiatan, serta belum optimal dalam menindaklanjuti rekomendasi BPK RI atas Laporan Hasil Pemeriksaan (LHP) sebelumnya.

Secara konseptual terdapat berbagai faktor yang menentukan kualitas pelaporan keuangan. Menurut Rezaee (2003), ada enam faktor yang menentukan kualitas pelaporan keuangan yaitu: board of directors, internal auditor, audit commitee, external auditor, top management team, governing bodies. ${ }^{1}$ Sedangkan Bauwhede (2001) mengemukakan bahwa faktor potensial yang mempengaruhi kualitas laporan keuangan, yaitu: management's decisions, quality of external governance mechanisms (i.e. audit quality), quality of internal governance mechanisms (ie. quality of the board of directors), regulation as to financial

1 Zabihollah Rezaee, High-Quality Financial Reporting: The Six-Legged Stool. Strategic Finance, 2003, Vol. 84, No. 8; ABI/INFORM Research. 
reporting, and external and internal governance mechanism. $^{2}$

Laporan keuangan pemerintah daerah pada dasarnya merupakan asersi atau pernyataan dari pihak manajemen pemerintah daerah yang menginformasikan kepada pihak lain, yaitu pemangku kepentingan yang ada tentang kondisi keuangan pemerintah daerah. Pemeriksaan atas laporan keuangan dimaksudkan untuk menilai kewajaran laporan keuangan berdasarkan prinsip akuntansi yang berlaku umum di Indonesia. Untuk melindungi para pengguna laporan keuangan, maka diperlukan pihak ketiga, yaitu auditor yang independen dalam menilai kualitas laporan keuangan pemerintah daerah (Mardiasmo, 2006). ${ }^{3}$ BPK RI adalah institusi yang berwenang melakukan pemeriksaan atas pengelolaan dan tanggung jawab keuangan negara.

Melihat fenomena masih sedikitnya LKPD yang memperoleh opini WTP $( \pm 30 \%)$, dan mengingat bahwa di tahun 2015 seluruh entitas pelaporan wajib menerapkan basis akrual yang cenderung lebih sulit dibandingkan basis kas menuju akrual maka menarik untuk dikaji lebih lanjut faktor-faktor yang mempengaruhi kualitas laporan keuangan pemerintah daerah. Mengacu pada hasil evaluasi BPK dalam IHPS tahun 2014, faktor-faktor yang secara konseptual mempengaruhi kualitas laporan keuangan serta berbagai penelitian sebelumnya yang sejenis, maka penelitian ini menguji pengaruh komitmen manajemen, kompetensi sumber daya manusia, efektivitas peran auditor internal, kualitas sistem akuntansi dan tindak lanjut atas temuan dan rekomendasi BPK terhadap kualitas laporan keuangan pemerintah daerah.

Penelitian ini dikembangkan dari penelitian yang dilakukan Nurdiono (2014). ${ }^{4}$ Nurdiono menggunakan lima variabel independen yaitu: proporsi anggaran, efektivitas audit internal, opini

2 Heidi Vander Bauwhede, "What Factors Influence Financial Statement Quality a Frame and Some Empirical Evidence", Disampaikan pada The Euroconference on Financial Reporting and Regulatory Practices in Europe, Parlermo, Italy, 2001.

3 Mardiasmo, Perwujudan Transparansi dan Akuntabilitas Publik Melalui Akuntansi Sektor Publik: Suatu Sarana Good Governance, Jurnal Akuntansi Pemerintah, 2006, Vol. 2 No. 1, hlm.117.

4 Nurdiono, Analisis Hasil Audit Laporan Keuangan Pemerintah Daerah di Seluruh Indonesia, Disertasi tidak dipublikasikan, 2014, (Yogyakarta: FEB-UGM). periode sebelumnya, tindak lanjut temuan BPK dan kompetensi sumber daya manusia. Variabel independen dalam penelitian ini meliputi komitmen manajemen, kompetensi sumber daya manusia, efektivitas auditor internal, kualitas sistem akuntansi, dan penyelesaian tindak lanjut temuan BPK. Variabel kualitas sistem akuntansi diadopsi dari penelitian Widyaningsih, dkk (2011). ${ }^{5}$ Sedangkan variabel komitmen manajemen adalah variabel baru yang ditambahkan dalam penelitian ini untuk diuji pengaruhnya terhadap kualitas laporan keuangan pemerintah daerah.

Teori yang mendasari penelitian ini adalah stewardship theory yang memandang bahwa manajemen organisasi sebagai "stewards/ penatalayanan", akan bertindak dengan penuh kesadaran, arif dan bijaksana bagi kepentingan organisasi. Penelitian dilakukan pada pemerintah Kota Semarang. Pemerintah Kota Semarang telah menerapkan basis akrual sejak pertama kali menyusun laporan keuangan dan merupakan satusatunya entitas pelaporan di Indonesia yang telah menerapkan basis akrual sehingga menjadi tujuan studi banding bagi pemerintah daerah lainnya. Kota Semarang juga mengelola APBD yang cukup besar jika dibandingkan pemerintah daerah lainnya di Jawa Tengah. Kota Semarang juga telah meraih opini WTP dalam 2 (dua) tahun terakhir yaitu pada tahun 2012 dan 2013.

\subsection{Tujuan dan Manfaat Penelitian}

Tujuan dari penelitian ini adalah untuk mengetahui dan menganalisis pengaruh:

1. Komitmen manajemen terhadap kualitas laporan keuangan pemerintah daerah.

2. Kompetensi sumber daya manusia terhadap kualitas laporan keuangan pemerintah daerah.

3. Efektivitas auditor internal terhadap kualitas laporan keuangan pemerintah daerah.

4. Kualitas sistem akuntansi terhadap kualitas laporan keuangan pemerintah daerah.

5. Penyelesaian tindak lanjut temuan BPK terhadap kualitas laporan keuangan pemerintah daerah.

Penelitian ini diharapkan dapat memberi kontribusi terhadap pengembangan ilmu pengetahuan di bidang sektor publik khususnya pada akuntansi pemerintahan. Selain itu, penelitian

5 Aristanti Widyaningsih, et al., "Hubungan Efektivitas SAKD dan Pengendalian Intern Dengan Kualitas Akuntabilitas Keuangan Melalui Kualitas Informasi Laporan Keuangan Sebagai Variabel Intervening", Simposium Nasional Akuntansi XIV, 2011. 
ini diharapkan juga dapat memberikan informasi bagi praktisi akuntansi pemerintah mengenai peran komitmen manajemen, kompetensi sumber daya manusia, efektivitas auditor internal, kualitas sistem akuntansi dan penyelesaian tindak lanjut temuan BPK terhadap kualitas laporan keuangan pemerintah daerah.

\section{KERANGKA TEORI DAN PENGEM- BANGAN HIPOTESIS}

\subsection{Stewardship Theory}

Penelitian ini mendasarkan pada stewardship theory (Donaldson dan Davis, 1991), yang menggambarkan situasi dimana para manajemen tidaklah termotivasi oleh tujuan-tujuan individu tetapi lebih ditujukan pada sasaran hasil utama mereka untuk kepentingan organisasi. $^{6}$ Teori tersebut mengasumsikan bahwa adanya hubungan yang kuat antara kepuasan dan kesuksesan organisasi. Kesuksesan organisasi menggambarkan maksimalisasi utilitas kelompok principals dan manajemen. Maksimalisasi utilitas kelompok ini pada akhirnya akan memaksimumkan kepentingan individu yang ada dalam kelompok organisasi tersebut.

Teori stewardship sering disebut sebagai teori pengelolaan (penatalayanan), memandang manajemen sebagai stewards (pelayan/ penerima amanah/ pengelola) akan bertindak dengan penuh kesadaran, arif dan bijaksana bagi kepentingan organisasi. Implikasi teori stewardship terhadap penelitian ini, dipertimbangkan dapat menjelaskan hubungan antara variabel, dengan asumsi bahwa untuk melaksanakan amanah tersebut maka stewards (manajemen) akan mengalokasikan sumber daya dana serta strategi yang diperlukan untuk mendukung pengelolaan keuangan yang baik dan menyajikan pertanggungjawaban yang diperlukan dengan baik pula.

Tersedianya sumber daya manusia yang kompeten dan sistem akuntansi yang baik merupakan faktor penting guna mendukung steward dalam melaksanakan amanah yang menjadi tanggung jawabnya. Kemudian peran auditor internal yang efektif serta komitmen untuk menindaklanjuti saran dan rekomendasi BPK juga akan membantu steward dalam pengelolaan keuangan dan penyajian laporan keuangan yang berkualitas sebagai bentuk pertanggungjawaban yang diamanahkan oleh undang-undang.

6 L. Donaldson dan J.H. Davis, Stewardship Theory or Agency Theory: CEO Governance and Shareholder Return. Australian Journal of Management, 1991, Vol. 1, hlm. 49-65.

\subsection{Kualitas Laporan Keuangan Pemerintah Daerah}

Salah satu upaya konkrit untuk mewujudkan transparansi dan akuntabilitas pengelolaan keuangan negara adalah penyampaian laporan pertanggungjawaban keuangan pemerintah yang memenuhi prinsip tepat waktu dan disusun sesuai standar akuntansi pemerintah yang telah diterima secara umum. Pasal 31 UU Keuangan Negara menyatakan bahwa:

1. Gubernur/ Bupati/ Walikota menyampaikan rancangan peraturan daerah tentang pertanggungjawaban pelaksanaan APBD kepada DPRD berupa laporan keuangan yang telah diperiksa oleh BPK, selambat-lambatnya 6 (enam) bulan setelah tahun anggaran berakhir.

2. Laporan keuangan dimaksud setidak-tidaknya meliputi Laporan Realisasi APBD, Neraca, Laporan Arus Kas, dan Catatan atas Laporan Keuangan, yang dilampiri dengan laporan keuangan perusahaan daerah.

Melihat peranan laporan keuangan, penting bagi pemerintahan untuk memperhatikan kualitas dari laporan keuangan tersebut. Kualitas merupakan sesuatu yang memenuhi atau melebihi harapan ataupun kriteria yang telah ditetapkan. Kriteria untuk menilai kualitas laporan keuangan menurut PP No. 71 Tahun 2010 tentang Standar Akuntansi Pemerintah adalah dapat dipahami, relevan, andal dan dapat diperbandingkan yang disebut sebagai karakteristik kualitatif laporan keuangan pemerintah. Karakteristik kualitatif laporan keuangan pemerintah merupakan ukuranukuran normatif yang perlu diwujudkan dalam informasi laporan keuangan sehingga dapat memenuhi kualitas yang dikehendaki.

\subsection{Komitmen Manajemen}

Guna menciptakan organisasi dengan kinerja yang tinggi diperlukan komitmen manajemen yang tinggi dari pimpinan dan stafnya untuk mencapai hasil yang diinginkan (GAO, 2001). ${ }^{7}$ Bansal, et al. $(2004)^{8}$ mendefinisikan komitmen sebagai kekuatan yang mengikat seseorang pada suatu tindakan yang memiliki relevansi dengan satu atau lebih sasaran. Dalam konteks akuntabilitas

7 General Accounting Office, Managing For Results: Federal Managers' Views on Key Management Issues Vary Widely Across Agencies, 2001, MD: General Accounting Office, Gaithersburg, GA0-01-592.

8 H.S. Bansal, et al., A Three Component Model of Customer Commitment to Service Providers, 2004, Academy of Marketing Science, Vol. 32, No.3. 
keuangan pemerintah daerah, komitmen manajemen merupakan hal yang penting karena proses pengelolaan keuangan dan penyajian laporan keuangan yang berkualitas tidak akan berhasil tanpa komitmen yang kuat dari para pejabat terkait.

Shields (1995) menyatakan bahwa komitmen manajemen dapat dicerminkan dengan mengalokasikan sumber daya, tujuan, dan strategi pada berbagai rencana yang dianggap bernilai; menolak sumberdaya yang menghambat inovasi; dan memberikan dukungan politis yang diperlukan untuk memotivasi atau menekan para individu atau pihak lain yang menolak keberadaan inovasi. ${ }^{9}$ Dengan demikian, keberadaan komitmen manajemen yang tinggi akan meningkatkan akuntabilitas kinerja (Artley, 2001). ${ }^{10}$

Hal ini sejalan dengan teori stewardship yang memandang bahwa manajemen organisasi sebagai stewards akan bertindak dengan penuh kesadaran, arif dan bijaksana bagi kepentingan organisasi. Dalam hal ini maka manajemen pemerintah daerah akan memiliki komitmen yang kuat terhadap pengelolaan keuangan daerah yang baik. Berdasarkan uraian di atas maka dirumuskan hipotesis penelitian sebagai berikut:

H1: Komitmen manajemen berpengaruh positif terhadap kualitas laporan keuangan pemerintah daerah.

\subsection{Kualitas Sumber Daya Manusia}

Kualitas sumber daya manusia adalah kemampuan sumber daya manusia untuk melaksanakan tugas dan tanggung jawab yang diberikan kepadanya dengan bekal pendidikan, pelatihan, dan pengalaman yang cukup memadai (Widodo, 2001). ${ }^{11}$ Jika dikaitkan dengan teori stewardship, maka manajemen pemerintah daerah akan terdorong untuk meningkatkan kompetensi sumber daya manusia yang dimilikinya termasuk dalam hal ini sumber daya pengelolaan keuangan dan penyusun laporan keuangan.

9 M. Shields, An Empirical Analysis of Firm's Implementation Experiences With ActivityBased Costing, Journal of Management Accounting Research, 1995, No. 7, hlm. 1-28.

10 Will Artley, The Performance Management Handbook Volume 3: Establisihing Accountability for Performance, (USA: Performance-Based Management Special Interest Group, 2001).

11 Joko Widodo, Good Governance, Telaah dari Dimensi Akuntabilitas dan Kontrol Birokrasi Pada Era Desentralisasi dan Otonomi Daerah (Surabaya: Insan Cendekia, 2001).
Menurut Griffin (2004), sumber daya manusia dapat diukur melalui rata-rata pendidikan, pelatihan dan tingkat pengalaman. ${ }^{12}$ Pendidikan merupakan suatu kegiatan yang universal dalam kehidupan manusia. Pelatihan adalah proses sistematis mengubah tingkah laku sesorang untuk mencapai tujuan organisasi. Pelatihan yang baik, harus berkaitan dengan keahlian dan kemampuan untuk melaksanakan pekerjaanya. Pengalaman dilihat dari lamanya seseorang bekerja. Dengan pengalaman, seseorang akan terbiasa melakukan suatu pekerjaan dan mempunyai wawasan yang luas serta mudah beradaptasi dengan lingkungan.

Lebih lanjut, kompetensi merupakan suatu karakteristik dari seseorang yang memiliki keterampilan (skill), pengetahuan (knowledge), dan kemampuan (ability) untuk melaksanakan suatu pekerjaan (Hevesi, 2005). ${ }^{13}$ Keterampilan, pengetahuan dan kemampuan yang dimiliki oleh sumber daya manusia sangat penting karena ketiga hal ini merupakan hal pokok yang harus dimiliki agar seseorang dapat melaksanakan pekerjaannya dengan baik.

Berdasarkan uraian di atas, maka hipotesis kedua untuk penelitian ini adalah:

$\begin{array}{llll}\text { H2: } & \text { Kompetensi sumber daya } & \text { manusia } \\ & \text { berpengaruh positif terhadap } & \text { kualitas } \\ & \text { laporan keuangan pemerintahdaerah. }\end{array}$

\subsection{Efektivitas Auditor Internal}

Auditor internal dalam suatu instansi pemerintah berfungsi untuk menilai apakah sistem pengawasan internal yang telah ditetapkan berjalan dengan akurat serta setiap bagian benarbenar melaksanakan kebijakan sesuai dengan rencana dan prosedur yang telah ditetapkan. Auditor internal adalah pegawai negeri sipil (PNS) yang mempunyai jabatan fungsional auditor dan/ atau pihak lain yang diberi tugas, wewenang, tanggung jawab dan hak secara penuh oleh pejabat yang berwenang melaksanakan pengawasan pada instansi pemerintah untuk dan atas nama Aparat Pengawasan Internal Pemerintah (APIP).

Pengawasan intern adalah seluruh proses kegiatan audit, reviu, pemantauan, evaluasi, dan kegiatan pengawasan lainnya berupa asistensi, sosialisasi dan konsultansi terhadap penyelenggaraan tugas dan fungsi organisasi. Pengawasan yang dilaksanakan APIP diharapkan dapat memberikan masukan atau rekomendasi

12 Ricky W. Griffin, Manajemen, Edisi Ketujuh, Jilid 2, Terj. Gina Gania (Jakarta: Penerbit Erlangga, 2004).

13 G. Alan Hevesi, Standards for Internal Control in New York State Government, 2005. 
kepada pimpinan penyelenggara pemerintahan mengenai hasil, hambatan, ketidaksesuaian prosedur dan indikasi penyimpangan yang terjadi atas jalannya pemerintahan yang menjadi tanggung jawab para pimpinan penyelenggara pemerintahan tersebut. Dengan demikian pada saat BPK melakukan pemeriksaan, indikasi penyimpangan tersebut telah diperbaiki.

Meigs, et al. (1989) menyatakan bahwa fungsi utama seorang auditor internal selain mengadakan penyelidikan dan penilaian pengendalian intern yang diselenggarakan organisasi, juga memberikan rekomendasi berdasarkan temuan-temuan serta perbaikan untuk menghasilkan informasi laporan keuangan yang berkualitas. ${ }^{14}$ Hal senada disampaikan oleh Mulyadi dan Puradiredja (2003) yang menyatakan bahwa auditor internal melaksanakan kegiatan-kegiatan untuk menentukan kualitas kehandalan informasi yang disajikan dalam laporan keuangan, dengan tujuan, agar laporan keuangan yang dihasil handal, berkualitas dan dapat dipercaya oleh masyarakat. ${ }^{15}$

Teori stewardship menggambarkan manajemen sebagai stewards, dapat termotivasi untuk bertindak sesuai keinginan principal dan organisasi. Dalam hal ini pemerintah daerah akan mengoptimalkan peran auditor internal dalam proses penyajian laporan keuangan yang berkualitas. Mengacu pada pernyataan di atas, penelitian ini dimaksudkan untuk menguji kembali hubungan antara efektivitas auditor internal dengan kualitas laporan keuangan, sehingga hipotesis ketiga dari penelitian ini adalah:

H3: Efektivitas auditor internal berpengaruh positif terhadap kualitas laporan keuangan pemerintah daerah.

\subsection{Kualitas Sistem Akuntansi Pemerintah Daerah}

Sistem akuntansi pada pemerintah daerah lebih dikenal dengan nama sistem informasi keuangan daerah (SIKD). SIKD merupakan sistem yang mendokumentasikan, mengadministrasikan serta mengolah data pengelolaan keuangan daerah serta data terkait lainnya untuk disajikan sebagai informasi kepada masyarakat dan sebagai bahan pengambilan keputusan dalam rangka perencanaan, pelaksanaan dan pelaporan pertanggungjawaban pemerintah daerah.

14 Walter B. Meigs, et al., Principles of Auditing, Seventh Edition, (USA: Richard D. Irwin, Inc, 1989).

15 Mulyadi dan Kanaka Puradireja, Auditing, (Jakarta: Salemba Empat, 2003).
Hall (2004) mengungkapkan bahwa, "The quality of information generated by the accounting information system impacts management's ability to take actions and make decisions in connection with the organization's operations and to prepare reliable financial statements". ${ }^{16}$ Sedangkan Mulyadi (2001) mengkaitkan tujuan pengembangan sistem akuntansi tidak lain adalah untuk memperbaiki pengendalian akuntansi dan pengecekan intern, yaitu untuk memperbaiki tingkat keandalan (reliability) informasi akuntansi dan untuk menyediakan catatan lengkap mengenai pertanggungjawaban dan perlindungan kekayaan perusahaan. ${ }^{17}$ Sistem akuntansi yang lemah menyebabkan pengendalian intern lemah dan pada akhirnya laporan keuangan yang dihasilkan juga kurang handal dan kurang relevan untuk pembuatan keputusan (Mardiasmo, 2007). ${ }^{18}$

Teori stewardship mengasumsikan bahwa kepentingan manajer dan principal adalah konvergensi, artinya keduanya mempunyai tujuan yang sama menuju satu titik, yaitu untuk kepentingan organisasi. Dalam konteks ini, maka pemerintah daerah akan membangun sistem yang berkualitas guna mewujudkan penyajian laporan keuangan yang berkualitas. Berdasarkan uraian di atas maka hipotesis keempat dirumuskan sebagai berikut:

H4: Kualitas sistem akuntansi berpengaruh positif terhadap kualitas laporan keuangan pemerintah daerah.

\subsection{Tindak Lanjut Temuan BPK}

Hasil pemeriksaan BPK dituangkan dalam LHP yang memuat opini, temuan, kesimpulan, dan rekomendasi. Rekomendasi adalah saran dari pemeriksa berdasarkan hasil pemeriksaannya, yang ditujukan kepada orang dan/ atau badan yang berwenang untuk melakukan tindakan dan/ atau perbaikan. Pejabat pada entitas yang diperiksa wajib menindaklanjuti rekomendasi dalam LHP dan memberikan jawaban atau penjelasan kepada BPK tentang tindak lanjut atas rekomendasi tersebut. Jawaban atau penjelasan tersebut disampaikan kepada BPK selambat-lambatnya 60 (enam puluh) hari setelah LHP diterima.

BPK memantau pelaksanaan tindak lanjut rekomendasi hasil pemeriksaan dan memberitahukan hasil pemantauan tindak lanjut

16 James A. Hall, Accounting Information Systems, (South-Western: Thomson, 2004).

17 Mulyadi, Sistem Akuntansi, (Jakarta: Salemba Empat, 2001).

18 Mardiasmo, Otonomi dan Manajemen Keuangan Daerah, (Yogyakarta: Penerbit Andi, 2007). 
kepada lembaga perwakilan dalam hasil pemeriksaan semester. Menurut BPK, pemantauan tindak lanjut rekomendasi hasil pemeriksaan dan pemantauan penyelesaian kerugian negara adalah bagian dari upaya BPK untuk mendorong perbaikan pengelolaan dan tanggung jawab keuangan negara. Dalam konteks pemeriksaan LKPD, tindak lanjut hasil pemeriksaan bertujuan terciptanya peningkatan opini atas LKPD.

Teori stewardship menggambarkan manajemen sebagai stewards, dapat termotivasi untuk bertindak sesuai keinginan principal dan organisasi. Dalam hal ini pemerintah daerah akan termotivasi untuk menindaklanjuti temuan dan rekomendasi BPK secara optimal. Berdasarkan uraian di atas, maka hipotesis kelima penelitian ini adalah:

H5: Penyelesaian tindak lanjut temuan BPK berpengaruh positif terhadap kualitas laporan keuangan pemerintah daerah.

\subsection{Kerangka Pemikiran Teoritis}

Kerangka pemikiran untuk penelitian ini disusun seperti Gambar 2.1 berikut ini:

\section{Gambar 1. Kerangka Pemikiran}

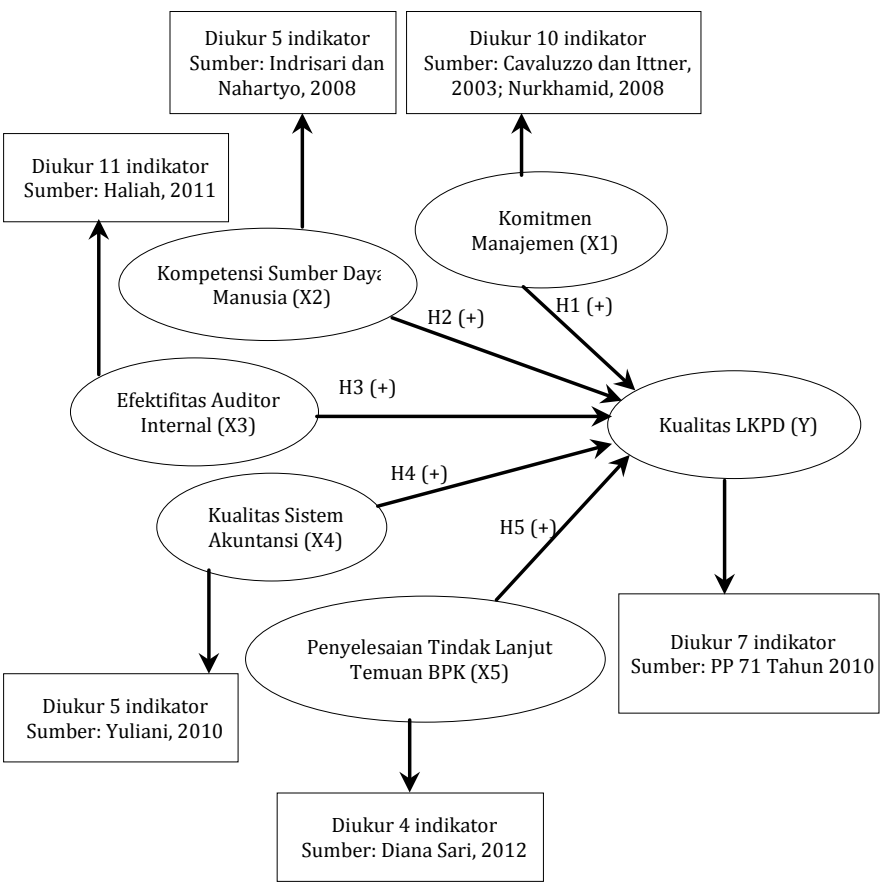

\section{METODOLOGI PENELITIAN}

\subsection{Populasi dan Sampel Penelitian}

Populasi dalam penelitian ini adalah seluruh Satuan Kerja Perangkat Daerah (SKPD) di lingkungan Pemerintah Kota Semarang yang seluruhnya berjumlah 50 SKPD. Pemilihan populasi tersebut didasarkan pada pertimbangan bahwa SKPD merupakan entitas pelaporan yang berkewajiban menyusun laporan keuangan atas anggaran yang dikelolanya. Penelitian ini menggunakan pendekatan sensus sehingga sampel adalah seluruh populasi yang berjumlah 50 tersebut.

\subsection{Variabel Penelitian dan Definisi Operasional Variabel}

Definisi operasional variabel, indikatorindikator yang digunakan dan skala pengukuran yang digunakan, disajikan dalam Tabel 2 berikut ini:

Tabel 2. Definisi Operasional Variabel dan Indikator Penelitian

\begin{tabular}{|c|c|}
\hline $\begin{array}{c}\text { Definisi } \\
\text { Operasional }\end{array}$ & Indikator \\
\hline \multicolumn{2}{|c|}{ Komitmen Manajemen (X1) } \\
\hline $\begin{array}{lr}\text { Komitmen } & \text { manajemen } \\
\text { pemerintah } & \text { daerah } \\
\text { untuk mengalokasikan } \\
\text { sumber daya dalam } \\
\text { proses pengelolaan } \\
\text { keuangan daerah dan } \\
\text { penyajian } \\
\text { keuangan. laporan }\end{array}$ & $\begin{array}{l}\text { 1. Komitmen pengelolaan keuangan } \\
\text { dan penyajian laporan keuangan } \\
\text { yang baik. } \\
\text { 2. Alokasi sumber daya. } \\
\text { 3. Mekanisme evaluasi internal. } \\
\text { 4. Pimpinan menuntut adanya } \\
\text { komitmen pengelolaan keuangan } \\
\text { dan penyajian laporan keuangan } \\
\text { yang baik. } \\
\text { 5. Menindaklanjuti rekomendasi } \\
\text { pihak eksternal. } \\
\text { 6. Pengaruh kurangnya komitmen/ } \\
\text { dukungan pimpinan. }\end{array}$ \\
\hline \multicolumn{2}{|c|}{ Kompetensi Sumber Daya Manusia (X2) } \\
\hline $\begin{array}{l}\text { Kemampuan pegawai } \\
\text { bagian akuntansi dan } \\
\text { keuangan dalam } \\
\text { melaksanakan tugas dan } \\
\text { fungsinya. }\end{array}$ & $\begin{array}{l}\text { 1. Latar belakang pendidikan yang } \\
\text { sesuai. } \\
\text { 2. Pelatihan dan pengembangan } \\
\text { secara periodik. } \\
\text { 3. Sumber daya manusia mampu } \\
\text { mengelola keuangan dan } \\
\text { menyajikan laporan keuangan. }\end{array}$ \\
\hline \multicolumn{2}{|c|}{ Efektivitas Auditor Internal (X3) } \\
\hline $\begin{array}{l}\text { Kemampuan auditor } \\
\text { internal untuk } \\
\text { memenuhi harapan atau } \\
\text { standar yang telah } \\
\text { ditetapkan. }\end{array}$ & $\begin{array}{l}\text { 1. Independensi auditor internal. } \\
\text { 2. Keahlian dan kecakapan auditor } \\
\text { internal. } \\
\text { 3. Pengawasan internal secara } \\
\text { berkala. } \\
\text { 4. Koordinasi dan komunikasi } \\
\text { dengan audetee. } \\
\text { 5. Penyampaian laporan hasil } \\
\text { pengawasan internal secara tepat } \\
\text { waktu. } \\
\text { 6. Saran dan rekomendasi mudah } \\
\text { dipahami dan dilaksanakan. } \\
\text { 7. Saran dan rekomendasi dari } \\
\text { auditor internal selalu } \\
\text { ditindaklanjuti. } \\
\text { 8. Audit internal berperan dalam } \\
\text { menunjang pengendalian } \\
\text { internal. }\end{array}$ \\
\hline
\end{tabular}




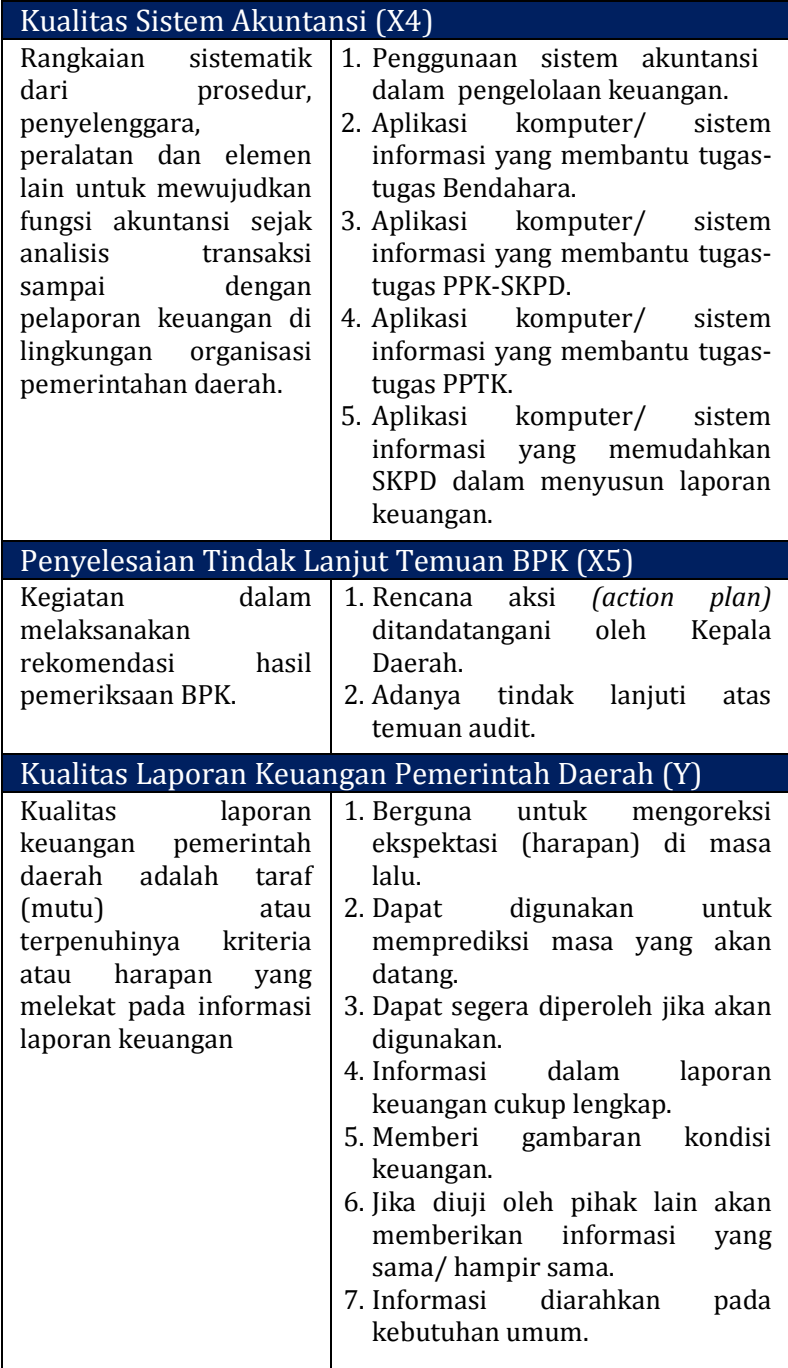

Sumber: Dari berbagai literatur, dikembangkan untuk penelitian ini (2015).

\subsection{Metode Pengumpulan Data}

Metode pengumpulan data dalam penelitian menggunakan teknik survei dimana metode survei ini digunakan untuk memperoleh data primer. Pengumpulan data pada penelitian ini menggunakan kuesioner.

\subsection{Teknik Analisis}

Teknik analisis yang digunakan dalam penelitian ini meliputi uji non response bias, statistik deskriptif, pengujian outer model, pengujian inner model dan uji hipotesis (path coefficients). Data dalam penelitian ini dianalisis dengan menggunakan metode Structural Equation Modelling (SEM) dari paket software PLS. Software yang digunakan adalah software Smart PLS versi 3.0.

\section{HASIL PENELITIAN}

\subsection{Data Penelitian}

Pemerintah Kota Semarang memiliki 50 SKPD yang berkewajiban untuk menyusun laporan keuangan. Dari 50 SKPD yang menjadi responden tersebut, 49 responden bersedia mengisi kuesioner yang dibagikan. Dari jumlah tersebut 46 kuesioner diterima kembali sebelum tanggal cut off dan sisanya 3 kuesioner diterima kembali setelah tanggal cut off. Demografi obyek penelitian yang telah dikumpulkan disajikan pada Tabel 3 dan Tabel 4 berikut ini:

Tabel 3. Kursus/ Diklat/ Bimtek di Bidang Pengelolaan Keuangan

\begin{tabular}{clcc} 
No. & $\begin{array}{c}\text { Kursus/ Diklat/ Bimtek } \\
\text { dalam 1 (satu) tahun } \\
\text { Terakhir }\end{array}$ & Responden & $\begin{array}{c}\text { Persentase } \\
\mathbf{( \% )}\end{array}$ \\
\hline 1 & Tidak Pernah & 4 & 8,16 \\
2 & Minim Sekali (1-2 kali) & 31 & 63,27 \\
3 & Pernah (3-5 kali) & 10 & 20,41 \\
4 & Sering (6-10 kali) & 4 & 8,16 \\
5 & Sangat Sering (11-20 kali) & 0 & 0,00 \\
\hline & Jumlah & $\mathbf{4 9}$ & $\mathbf{1 0 0}$ \\
\hline
\end{tabular}

Sumber: Data primer diolah (2015).

Tabel 4. Kursus/ Diklat/ Bimtek tentang Penyusunan Laporan Keuangan

\begin{tabular}{c|lcc} 
No. & $\begin{array}{l}\text { Kursus/ Diklat/ Bimtek } \\
\text { dalam 1 (satu) tahun }\end{array}$ & Responden & $\begin{array}{c}\text { Persentase } \\
\text { (\%) }\end{array}$ \\
\hline 1 & Tidak Pernah & 5 & 10,20 \\
2 & Minim Sekali (1-2 kali) & 33 & 67,35 \\
3 & Pernah (3-5 kali) & 10 & 20,41 \\
4 & Sering (6-10 kali) & 1 & 2,04 \\
5 & Sangat Sering (11-20 kali) & 0 & 0 \\
\hline \multicolumn{2}{r}{ Jumlah } & $\mathbf{4 9}$ & $\mathbf{1 0 0}$ \\
\hline
\end{tabular}

Sumber: Data primer diolah (2015).

\subsection{Analisis Data}

\subsubsection{Statistik Deskriptif}

Analisis statistik deskriptif merupakan teknik analisis data yang digunakan untuk memberikan gambaran tentang karakteristik sampel. Statistik deskriptif untuk keseluruhan variabel meliputi kisaran nilai minimum dan maksimum baik secara teoritis maupun aktual, nilai rata-rata (mean), dan simpangan baku (standard deviation) dari tanggapan responden terhadap variabel-variabel dalam instrumen penelitian (kuesioner). Nilai kisaran teoritis, kisaran aktual, mean dan standard deviation setiap variabel disajikan pada Tabel 5 . 
Tabel 5. Statistik Deskriptif

\begin{tabular}{|l|c|c|c|c|c|}
\hline \multirow{2}{*}{ Variabel } & \multicolumn{2}{|c|}{ Teoritis } & \multicolumn{2}{c|}{ Aktual } & $\begin{array}{l}\text { Standar } \\
\text { Deviasi }\end{array}$ \\
\cline { 2 - 6 } & Kisaran & Mean & Kisaran & Mean & \\
\hline Komitmen Manajemen & $4-20$ & 12.0 & $4-20$ & 15,94 & 2,617 \\
\hline Kompetensi SDM & $4-20$ & 12.0 & $4-20$ & 15,82 & 2,455 \\
\hline Efektifitas Auditor Internal & $3-15$ & 9.0 & $4-15$ & 12,22 & 1,636 \\
\hline Kualitas Sistem Akuntansi & $4-20$ & 12.0 & $4-20$ & 16,27 & 2,361 \\
\hline Penyelesaian TLBPK & $2-10$ & 6.0 & $5-10$ & 8,18 & 0,993 \\
\hline Kualitas LKPD & $4-20$ & 12.0 & $4-20$ & 16,41 & 2,483 \\
\hline Sumber: Data primer diolah (2015).
\end{tabular}

\subsubsection{Uji Non-Respon Bias (T-Test)}

Uji non-response bias dilakukan dengan cara membandingkan jawaban untuk setiap konstruk antara responden yang berpartisipasi dengan responden yang tidak berpartisipasi. Responden yang mengembalikan kuesioner setelah batas akhir yang telah ditentukan yaitu 2 minggu (late response), dianggap mewakili responden yang tidak menjawab atau tidak berpartisipasi. Pengujian non-response bias dilakukan dengan menggunakan alat analisis uji beda yaitu independen $t$-test. Hasil $t$-test semua variabel menunjukkan bahwa nilai $p$-value $>0,05$, sehingga dapat disimpulkan tidak terdapat perbedaan jawaban yang diberikan oleh kedua kelompok responden (sebelum dan setelah cut-off).

\subsubsection{Evaluasi Model Pengukuran/ Measurement (Outer) Model}

\subsubsection{Validitas Konvergen (Convergent Validity)}

Pengukuran validitas konvergen bertujuan untuk mengetahui validitas setiap hubungan antara indikator dengan variabel latennya. Validitas konvergen dari model pengukuran dengan reflektif indikator dinilai berdasarkan korelasi antara skor item atau component score dengan skor variabel laten atau construct score yang dihitung dengan PLS. Validitas konvergen dalam penelitian ini menggunakan nilai loading faktor dan nilai Average Variance Extracted (AVE).

Nilai loading memiliki tingkat validitas tinggi apabila memiliki nilai faktor loading lebih besar dari $\quad 0,70$ (Ghozali 2015). ${ }^{19}$ Indikator yang digunakan dalam penelitian ini memiliki nilai faktor loading lebih besar dari 0,70 sebagaimana disajikan pada Tabel 6.

19 Imam Ghozali dan Hengky Latan, Partial Least Square Konsep, Teknik dan Aplikasi Menggunakan Program SmartPLS 3.0, edisi 2, (Semarang: Badan Penerbit Universitas Diponegoro, 2015).
Tabel 6. Nilai Outer Loading

\begin{tabular}{|c|c|c|c|c|c|c|}
\hline Indikator & $\begin{array}{l}\text { Komitmen } \\
\text { Manajemen }\end{array}$ & $\begin{array}{c}\text { Kompetensi } \\
\text { Sumber Daya } \\
\text { Manusia }\end{array}$ & $\begin{array}{c}\text { Efektifitas } \\
\text { Auditor } \\
\text { Intermal }\end{array}$ & $\begin{array}{l}\text { Kualitas } \\
\text { Sistem } \\
\text { Akuntansi }\end{array}$ & $\begin{array}{c}\text { Penyelesaian } \\
\text { TL BPK }\end{array}$ & $\begin{array}{l}\text { Kualitas } \\
\text { LKPD }\end{array}$ \\
\hline KM2 & 0.796 & & & & & \\
\hline KM3 & 0.860 & & & & & \\
\hline KM4 & 0.875 & & & & & \\
\hline KM6 & 0.740 & & & & & \\
\hline SDM2 & & 0.894 & & & & \\
\hline $\mathrm{SDM} 3$ & & 0.883 & & & & \\
\hline SDM4 & & 0.861 & & & & \\
\hline SDM5 & & 0.863 & & & & \\
\hline EAI2 & & & 0.886 & & & \\
\hline EAI9 & & & 0.899 & & & \\
\hline EAI11 & & & 0.915 & & & \\
\hline SAPD1 & & & & 0.905 & & \\
\hline SAPD2 & & & & 0.916 & & \\
\hline SAPD4 & & & & 0.776 & & \\
\hline SAPD5 & & & & 0.910 & & \\
\hline TLBPK3 & & & & & 0.964 & \\
\hline TLBPK 4 & & & & & 0.787 & \\
\hline LKPD1 & & & & & & 0.876 \\
\hline LKPD2 & & & & & & 0.920 \\
\hline LKPD4 & & & & & & 0.758 \\
\hline LKPD7 & & & & & & 0.718 \\
\hline
\end{tabular}

Sumber: Data primer diolah (2015).

Konstruk dikatakan memiliki reliabilitas yang tinggi jika nilai AVE berada di atas 0,50. Selanjutnya nilai AVE untuk variabel komitmen manajemen, kompetensi SDM, efektivitas auditor internal, kualitas sistem akuntansi, penyelesaian TLBPK dan variabel kualitas LKPD menunjukkan nilai lebih besar 0,50 sebagaimana tersaji pada Tabel 7.

Tabel 7. Nilai AVE Masing-Masing Variabel

\begin{tabular}{|l|c|c|}
\hline \multicolumn{1}{|c|}{ Variabel } & $\begin{array}{c}\text { Average Variance Extracted } \\
\text { (AVE) }\end{array}$ & Kriteria \\
\hline Komitmen Manajemen & 0.672 & Baik \\
\hline Kompetensi SDM & 0.766 & Baik \\
\hline Efektifitas Auditor Internal & 0.810 & Baik \\
\hline Kualitas Sistem Akuntansi & 0.772 & Baik \\
\hline Penyelesaian TLBPK & 0.774 & Baik \\
\hline Kualitas LKPD & 0.676 & Baik \\
\hline
\end{tabular}

Sumber: Data primer diolah (2015).

\subsubsection{Validitas Diskriminan (Discriminant Validity)}

Model memiliki validitas diskriminan yang baik jika akar kuadrat AVE untuk setiap konstruk lebih besar dari korelasi antara dua konstruk di dalam model. Nilai akar kuadrat AVE yang diperoleh dari hasil pengujian atas semua variabel menunjukkan nilai yang lebih tinggi dari nilai korelasi sebagaimana tersaji pada Tabel 8 . 
Tabel 8. Nilai Discriminant Validity

\begin{tabular}{|l|c|c|c|c|c|c|}
\hline & $\begin{array}{c}\text { Efektivitas } \\
\text { Auditor } \\
\text { Internal }\end{array}$ & Manajemen & $\begin{array}{c}\text { Kompetens } \\
\text { SDM }\end{array}$ & $\begin{array}{c}\text { Kualitas } \\
\text { LKPD }\end{array}$ & $\begin{array}{c}\text { Kualitas } \\
\text { Sistem } \\
\text { Akuntansi }\end{array}$ & $\begin{array}{c}\text { Penyelesaian } \\
\text { TLBPK }\end{array}$ \\
\hline $\begin{array}{l}\text { Efektifitas } \\
\text { Auditor } \\
\text { Internal }\end{array}$ & $\mathbf{0 . 9 0 0}$ & & & & & \\
\hline $\begin{array}{l}\text { Komitmen } \\
\text { Manajemen }\end{array}$ & 0.795 & $\mathbf{0 . 8 2 0}$ & & & & \\
\hline $\begin{array}{l}\text { Kompetensi } \\
\text { SDM }\end{array}$ & 0.759 & 0.746 & $\mathbf{0 . 8 7 5}$ & & & \\
\hline $\begin{array}{l}\text { Kualitas } \\
\text { LKPD }\end{array}$ & 0.743 & 0.674 & 0.695 & $\mathbf{0 . 8 2 2}$ & & \\
\hline $\begin{array}{l}\text { Kualitas } \\
\text { Sistem } \\
\text { Akuntansi }\end{array}$ & 0.746 & 0.690 & 0.832 & 0.762 & $\mathbf{0 . 8 7 9}$ & \\
\hline $\begin{array}{l}\text { Penyelesaian } \\
\text { TLBPK }\end{array}$ & 0.749 & 0.696 & 0.706 & 0.736 & 0.710 & $\mathbf{0 . 8 8 0}$ \\
\hline \multicolumn{1}{|l|}{} & & & & & \\
\hline
\end{tabular}

Sumber: Data primer diolah (2015).

\subsubsection{Uji Reliabilitas}

Uji reliabilitas pada penelitian ini dilakukan dengan melihat nilai cronbach alpha dan composite reliability. Reliabilitas dikatakan baik jika nilai cronbach alpha dan composite reliability lebih besar dari 0,70. Nilai cronbach alpha dan composite reliability masing-masing variabel dalam penelitian ini menunjukkan nilai lebih besar 0,70 sebagaimana disajikan pada Tabel 9.

Tabel 9. Nilai Cronbach Alpha dan Composite Reliability

\begin{tabular}{|l|c|c|}
\hline \multicolumn{1}{|c|}{ Variabel } & Cronbachs Alpha & Composite Reliability \\
\hline Komitmen Manajemen & 0.835 & 0.891 \\
\hline Kompetensi SDM & 0.899 & 0.929 \\
\hline Efektifitas Auditor Internal & 0.885 & 0.928 \\
\hline Kualitas Sistem Akuntansi & 0.901 & 0.931 \\
\hline Penyelesaian TLBPK & 0.746 & 0.872 \\
\hline Kualitas LKPD & 0.836 & 0.892 \\
\hline
\end{tabular}

Sumber: Data primer diolah (2015).

\subsubsection{Pengujian Model Struktural (Inner Model)}

Menilai model struktural dengan PLS dimulai dengan melihat $R$-squared untuk setiap variabel endogen. Hasil pengujian menunjukkan nilai adjusted R-squared untuk kualitas LKPD sebesar 0,6438 atau $64,38 \%$. Hasil tersebut menunjukkan bahwa variabel eksogen yang meliputi komitmen manajemen, kompetensi sumber daya manusia, efektivitas auditor internal, kualitas sistem akuntansi dan penyelesaian tindak lanjut temuan BPK berpengaruh terhadap variabel kualitas LKPD sebesar 0,6438 atau 64,38\% sedangkan sebesar 0,3562 atau $35,62 \%$ dipengaruhi oleh variabel lainnya. Nilai adjusted $R$-squared ini termasuk dalam kategori moderat.

Nilai Stone-Geisser $Q^{2}$ dengan menggunakan SmartPLS didapat dengan melalui prosedur blindfolding. Nilai $\mathrm{Q}^{2}$ variabel endogen kualitas LKPD sebesar 0,342 tersaji pada Tabel 10. Nilai $Q^{2}$ variabel endogen tersebut lebih besar dari nol $\left(\mathrm{Q}^{2}\right.$ $>0$ ) yang menunjukkan bahwa model mempunyai predictive relevance.

Tabel 10. Nilai Q2 Variabel Endogen

\begin{tabular}{|l|c|c|c|}
\hline \multicolumn{1}{|c|}{ Variabel } & \multicolumn{1}{c|}{ SSO } & SSE & $\begin{array}{c}\text { Q2 (=1- } \\
\text { SSE/SSO })\end{array}$ \\
\hline Komitmen Manajemen & 196.000 & 196.000 & \\
\hline Kompetensi SDM & 196.000 & 196.000 & \\
\hline Efektivitas Auditor Internal & 147.000 & 147.000 & \\
\hline Kualitas Sistem Akuntansi & 196.000 & 196.000 & \\
\hline Penyelesaian TLBPK & 98.000 & 98.000 & \\
\hline Kualitas LKPD & 196.000 & 196.000 & 0.342 \\
\hline
\end{tabular}

Sumber: Data primer diolah (2015).

\subsection{Pengujian Hipotesis}

Pengujian hipotesis mengenai hubungan yang dikembangkan dalam model penelitian menggunakan besaran nilai $t$-statistics dan $p$-value sebagai dasar dari signifikansi hubungan antara variabel laten eksogen dan endogen. Penelitian ini menggunakan tingkat signifikansi 5\% karena jenis data yang diolah adalah data primer serta dianggap tidak memiliki ketelitian yang tinggi. Nilai $t$ statistics $>1.671$ dan $p$-value $<0.05$ dikatakan signifikan pada alpha $5 \%$ yang berarti hipotesis diterima pada alpha $5 \%$. Nilai $t$-statistik dan $p$ value pada penelitian ini dengan menggunakan SmartPLS, dilihat dari output Path Coefficients sebagaimana disajikan pada pada Tabel 11:

Tabel 11. Hasil Output Path Coefficients dan P-Value

\begin{tabular}{|l|c|c|c|c|c|}
\hline \multicolumn{1}{|c|}{ Hipotesis } & $\begin{array}{c}\text { Original } \\
\text { Sample } \\
(0)\end{array}$ & $\begin{array}{c}\text { Sample } \\
\text { Mean } \\
\text { (M) }\end{array}$ & $\begin{array}{c}\text { Standard } \\
\text { Error } \\
\text { (STERR) }\end{array}$ & $\begin{array}{c}\text { T Statistics } \\
\text { (O/STERR) }\end{array}$ & $\begin{array}{c}\text { P } \\
\text { Values }\end{array}$ \\
\hline $\begin{array}{l}\text { Komitmen Manajemen } \rightarrow \\
\text { Kualitas LKPD }\end{array}$ & 0.068 & 0.071 & 0.176 & 0.384 & 0.351 \\
\hline $\begin{array}{l}\text { Kompetensi SDM } \rightarrow \\
\text { Kualitas LKPD }\end{array}$ & -0.044 & -0.031 & 0.189 & 0.232 & 0.408 \\
\hline $\begin{array}{l}\text { Efektifitas Auditor } \\
\text { Internal } \rightarrow \text { Kualitas LKPD }\end{array}$ & 0.229 & 0.208 & 0.176 & 1.301 & 0.097 \\
\hline $\begin{array}{l}\text { Kualitas Sistem Akuntansi } \\
\rightarrow \text { Kualitas LKPD }\end{array}$ & 0.386 & 0.345 & 0.203 & 1.904 & 0.029 \\
\hline $\begin{array}{l}\text { Penyelesaian TLBPK } \rightarrow \\
\text { Kualitas LKPD }\end{array}$ & 0.274 & 0.292 & 0.151 & 1.821 & 0.035 \\
\hline
\end{tabular}

Sumber: Data primer diolah (2015).

Dari tabel terlihat bahwa variabel kualitas sistem akuntansi dan penyelesaian tindak lanjut temuan BPK berpengaruh positif terhadap variable kualitas LKPD masing-masing sebesar 0,386 dan 0,274 dengan nilai $t$-statistics $>1,671$ dan $p$-value $<$ 0,05 yang artinya signifikan pada alpha $5 \%$. Namun demikian variabel komitmen manajemen, kompetensi sumber daya manusia dan efektivitas auditor internal tidak signifikan mempengaruhi kualitas LKPD pada alpha 5\%.

Hipotesis pertama (H1) menyatakan bahwa komitmen manajemen berpengaruh positif terhadap kualitas laporan keuangan pemerintah 
daerah. Hasil pengujian ditunjukkan pada Tabel 11 baris pertama. Berdasarkan tabel tersebut, hasil uji terhadap koefisien parameter beta pada original sample dan sample mean antara komitmen manajemen dengan kualitas LKPD terdapat pengaruh positif masing-masing sebesar 0,068 dan 0,071 dengan nilai t-statistisc sebesar 0,384 $(<1.671)$ dan nilai p-value sebesar 0,351 ( $p>0.05)$ yang berarti tidak signifikan pada alpha $5 \%$. Dengan demikian hipotesis pertama (H1) ditolak. Hal ini dapat disimpulkan bahwa komitmen manajemen tidak cukup signifikan mempengaruhi kualitas LKPD yang disajikan pada tingkat signifikansi 5\%.

Hipotesis kedua (H2) menyatakan bahwa kompetensi sumber daya berpengaruh positif terhadap kualitas laporan keuangan pemerintah daerah. Hasil pengujian ditunjukan pada Tabel 11 baris kedua. Sesuai tabel tersebut terlihat bahwa hasil uji terhadap koefisien parameter beta pada original sample antara sumber daya manusia dengan kualitas LKPD terdapat pengaruh negatif sebesar 0,044 dengan nilai t-statistisc sebesar $0,232(<1.671)$ dan $\mathrm{p}$-value sebesar $0,408(\mathrm{p}>0.05)$ yang berarti tidak signifikan pada alpha $5 \%$. Nilai koefisien parameter beta sample mean (500 resampling) antara sumber daya manusia dengan kualitas LKPD juga tetap bertanda negatif sebesar 0,031 . Hal ini menandakan bahwa apabila dengan resampling 500 sampel koefisien parameter beta juga akan tetap negatif dan tidak signifikan. Dengan demikian hipotesis kedua (H2) ditolak. Oleh karena itu dapat disimpulkan bahwa kompetensi sumber daya manusia pada Pemerintah Kota Semarang baik berupa sumber daya manusia pengelola keuangan maupun penyusun pertanggungjawabannya tidak memberikan dampak yang signifikan dalam proses penyusunan laporan keuangan.

Hipotesis ketiga (H3) menyatakan bahwa efektivitas auditor internal berpengaruh positif terhadap kualitas laporan keuangan pemerintah daerah. Hasil pengujian ditunjukan pada Tabel 11 baris ketiga. Berdasarkan tabel tersebut, bahwa hasil uji terhadap koefisien parameter beta pada original sample dan sample mean antara efektivitas auditor internal dengan kualitas LKPD terdapat pengaruh positif masing-masing sebesar 0,229 dan 0,208 dengan nilai $t$-statistisc sebesar 1,301 $(<1.671)$ dan nilai $p$-value sebesar 0,097 ( $p>0.05)$ yang berarti tidak signifikan pada alpha 5\%. Dengan demikian hipotesis ketiga tersebut (H3) ditolak. Hal ini dapat disimpulkan bahwa peran auditor internal dalam melakukan review atas penyajian laporan keuangan tidak signifikan mempengaruhi kualitas laporan keuangan yang disajikan pada tingkat signifikansi 5\%.
Hipotesis keempat (H4) menyatakan bahwa kualitas sistem akuntansi berpengaruh positif terhadap kualitas laporan keuangan pemerintah daerah. Hasil pengujian disajikan pada Tabel 11 baris keempat. Berdasarkan tabel tersebut, hasil uji terhadap koefisien parameter beta pada original sample dan sample mean antara kualitas sistem akuntansi dengan kualitas LKPD terdapat pengaruh positif masing-masing sebesar 0,386 dan 0,345 dengan nilai $t$-statistisc sebesar 1,904 (>1.671) dan nilai p-value sebesar 0,029 ( $<$ < 0.05) yang berarti signifikan pada alpha $5 \%$. Dengan demikian hipotesis empat (H4) tersebut diterima. Hal ini dapat disimpulkan bahwa kualitas sistem akuntansi yang digunakan dalam proses penyusunan laporan keuangan pada Pemerintah Kota Semarang memberikan pengaruh yang signifikan terhadap kualitas LKPD yang disajikan pada tingkat signifikansi $5 \%$.

Hipotesis kelima (H5) menyatakan bahwa penyelesaian tindak lanjut temuan BPK berpengaruh positif terhadap kualitas LKPD. Hasil pengujian ditunjukan pada Tabel 11 baris kelima. Berdasarkan tabel tersebut, bahwa hasil uji terhadap koefisien parameter beta pada original sample dan sample mean antara sistem sanksi dengan penganggaran berbasis kinerja terdapat pengaruh positif masing-masing sebesar 0,274 dan 0,292 dengan nilai t-statistisc sebesar 1,821 $(>1.671)$ dan nilai $p$-value sebesar $0,035(\mathrm{p}<0.05)$ yang berarti tidak signifikan pada alpha $5 \%$. Dengan demikian hipotesis kelima (H5) ditolak. Hal ini dapat disimpulkan bahwa komitmen dalam penyelesaian tindak lanjut temuan BPK memberikan dampak yang signifikan terhadap kualitas laporan keuangan yang disajikan pada tingkat signifikansi 5\%.

\subsection{Pembahasan}

Ringkasan hasil pengujian disajikan pada Tabel 12:

Tabel 12. Ringkasan Hasil Pengujian Hipotesis

\begin{tabular}{|c|c|c|c|c|c|}
\hline No. & Hipotesis & $\begin{array}{c}\text { Koefisien } \\
\beta \text { Original } \\
\text { Sample }\end{array}$ & $\begin{array}{l}\text { Koefisien } \\
\beta \text { Sample } \\
\text { Mean }\end{array}$ & $p$-value & $\begin{array}{c}\text { Hasil } \\
\text { Pengujian }\end{array}$ \\
\hline H1 & $\begin{array}{l}\text { Komitmen manajemen } \\
\text { berpengaruh positif terhadap } \\
\text { kualitas LKPD }\end{array}$ & 0.068 & 0.068 & 0.351 & Ditolak \\
\hline $\mathrm{H} 2$ & $\begin{array}{l}\text { Kompetensi sumber daya } \\
\text { manusia berpengaruh positif } \\
\text { terhadap kualitas LKPD } \\
\end{array}$ & -0.044 & -0.031 & 0.408 & Ditolak \\
\hline H3 & $\begin{array}{l}\text { Efektifitas auditor internal } \\
\text { berpengaruh positif terhadap } \\
\text { kualitas LKPD }\end{array}$ & 0.229 & 0.208 & 0.097 & Ditolak \\
\hline H4 & $\begin{array}{l}\text { Kualitas Sistem Akuntansi } \\
\text { berpengaruh positif terhadap } \\
\text { kualitas LKPD }\end{array}$ & 0.386 & 0.345 & 0.029 & Diterima \\
\hline H5 & $\begin{array}{l}\text { Penyelesaian tindak lanjut } \\
\text { temuan BPK berpengaruh } \\
\text { positif terhadap kualitas } \\
\text { LKPD }\end{array}$ & 0.274 & 0.292 & 0.035 & Diterima \\
\hline
\end{tabular}

Sumber: Data primer diolah (2015). 


\subsubsection{Komitmen Manajemen Berpengaruh Positif terhadap Kualitas LKPD}

Hasil pengujian hipotesis menunjukkan bahwa hipotesis ke-1 komitmen manajemen berpengaruh positif terhadap kualitas LKPD ditolak. Komitmen manajemen berpengaruh positif tetapi tidak signifikan terhadap kualitas LKPD dengan koefisien jalur 0,068.

Berdasarkan jawaban responden komitmen pimpinan untuk mewujudkan laporan keuangan yang berkualitas masih belum optimal. Nilai loading factor variabel komitmen manajemen berada dalam kisaran 0,740 sampai dengan 0,875, dimana indikator SKPD mempunyai mekanisme evaluasi internal dalam mewujudkan laporan keuangan yang berkualitas dan pimpinan selalu menunjukkan komitmen yang kuat untuk mewujudkan laporan keuangan yang berkualitas, menunjukkan loading factor sebesar 0,740 dan 0,796. Sedangkan indikator pimpinan mengalokasikan sumber daya yang memadai seperti dana, SDM, dan sistem/ aplikasi dalam proses pengelolaan keuangan yang baik, dan pimpinan mengalokasikan sumber daya yang memadai seperti dana, SDM, dan sistem/ aplikasi dalam mewujudkan laporan keuangan yang berkualitas menunjukkan loading factor sebesar 0,860 dan 0,875 .

Komitmen manajemen di lingkungan Pemerintah Kota Semarang yang masih belum optimal tidak mempengaruhi kualitas LKPD yang disajikan. Kualitas LKPD pemerintah Kota Semarang sudah relatif baik. Hal ini ditunjukkan dengan jawaban responden dimana nilai rata-rata aktual kualitas LKPD sebesar 16,41 yang lebih tinggi dibandingkan dengan rata-rata teoritisnya sebesar 12,00 (Tabel 5).

Hasil penelitian ini tidak sejalan dengan teori stewardship yang mengasumsikan bahwa manajemen organisasi sebagai "stewards", akan bertindak dengan penuh kesadaran, arif dan bijaksana bagi kepentingan organisasi. Mengacu pada jawaban responden gagalnya penelitian ini mendukung hipotesis ke-1 kemungkinan disebabkan kurang kuatnya komitmen pimpinan SKPD di lingkungan Pemerintah Kota Semarang untuk mewujudkan laporan keuangan yang berkualitas dan masih lemahnya mekanisme evaluasi internal guna mendukung terwujudnya laporan keuangan yang berkualitas.

Hasil penelitian tidak sejalan dengan penelitian yang dilakukan oleh Silviana (2011) ${ }^{20}$

20 Silviana, Pengaruh Komitmen Kepala Daerah terhadap Kualitas Laporan Keuangan Pemerintah Daerah, 2011. yang menyatakan bahwa komitmen kepala daerah berpengaruh positif secara signifikan terhadap kualitas LKPD. Hasil penelitian ini juga tidak sejalan dengan penelitian Cavalluzzo dan Ittner (2003) ${ }^{21}$, Nurkhamid (2008) $)^{22}$, Akbar et al. (2012) $^{23}$ yang menyatakan bahwa komitmen manajemen berpengaruh positif secara signifikan terhadap akuntabilitas kinerja.

\subsubsection{Kompetensi Sumber Daya Manusia Berpengaruh Positif terhadap Kualitas LKPD}

Hasil pengujian hipotesis menunjukkan bahwa hipotesis ke-2 kompetensi sumber daya manusia berpengaruh positif terhadap kualitas laporan keuangan pemerintah daerah ditolak. Kompetensi sumber daya manusia berpengaruh negatif tetapi tidak signifikan terhadap kualitas LKPD dengan koefisien jalur 0,044.

Berdasarkan jawaban responden, sumber daya manusia bidang pengelolaan keuangan dan penyajian laporan keuangan pada pemerintah daerah Kota Semarang belum sepenuhnya memiliki kompetensi yang memadai. Nilai loading factor variabel kompetensi sumber daya manusia berada dalam kisaran 0,861 sampai dengan 0,894, dimana indikator SKPD memiliki sumber daya manusia yang mampu mengelola keuangan dengan baik dan SKPD memiliki sumber daya manusia yang mampu mengelola keuangan dengan baik menyusun laporan keuangan yang berkualitas menunjukkan loading factor sebesar 0,861 dan 0,863 . Sedangkan indikator pelatihan untuk membantu penguasaan dan pengembangan keahlian dalam tugas pengelolaan keuangan dan penyusunan laporan keuangan dilakukan secara periodik menunjukkan loading factor sebesar 0,883 dan 0,894 .

Pendidikan dan pelatihan terkait pengelolaan keuangan dan penyajian laporan keuangan telah dilakukan namun intensitasnya sangat sedikit sehingga tidak cukup memadai untuk mendukung peningkatan kompetensi pegawai. Statistik deskriptif menunjukkan $63,27 \%$ responden menyatakan kursus/ pendidikan dan pelatihan/ bimbingan teknis di bidang pengelolaan keuangan yang diikuti oleh pegawai pada unit kerja

21 Ken S. Cavalluzzo dan Christopher D. Ittner, Implementing Performance Measurement Innovations: Evidence from Government, 2003, diakses dari www.ssrn.com, hlm. 1-54.

22 M. Nurkhamid, Implementasi Inovasi Sistem Pengukuran Kinerja Instansi Pemerintah. Jurnal Akuntansi Pemerintah, 2008, Vol. 3 No. 1.

23 R. Akbar, et al., Performance Measurement in Indonesia: the Case of Local Goverment, 2012. 
responden dalam satu tahun terakhir hanya sebanyak (1-2) kali. Begitu pula dengan kursus/ pendidikan dan pelatihan/ bimbingan teknis tentang penyusunan laporan keuangan yang diikuti oleh pegawai pada unit kerja responden dalam satu tahun terakhir, sebanyak 67,35\% responden menyatakan hanya sebanyak (1-2) kali. Dengan demikian hasil penelitian ini tidak sejalan dengan asumsi-asumsi dasar (fundamental assumptions of stewardship theory) yang menggambarkan bahwa para pimpinan tidak termotivasi oleh tujuan-tujuan individu tetapi lebih ditujukan pada sasaran utama untuk kepentingan organisasi sehingga steward (manajemen) bertindak sesuai keinginan principal.

Pengembangan kompetensi sumber daya manusia yang belum optimal di lingkungan Pemerintah Kota Semarang tidak mempengaruhi kualitas LKPD yang disajikan. Hal ini ditunjukkan dengan jawaban responden atas kualitas LKPD yang sudah relatif baik dimana nilai rata-rata aktual kualitas LKPD sebesar 16,41 yang lebih tinggi dibandingkan dengan rata-rata teoritisnya sebesar 12,00 (Tabel 5).

Hasil penelitian ini sejalan dengan penelitian yang dilakukan oleh Indriasari dan Ertambang $(2008)^{24}$ dan Nurdiono (2014) ${ }^{25}$, tetapi tidak sejalan dengan penelitian yang dilakukan oleh $\mathrm{Xu}$, et al. (2003) ${ }^{26}$, Choirunisah $(2008)^{27}$ dan Subadriyah (2014) ${ }^{28}$ yang menyatakan bahwa kompetensi sumber daya manusia berpengaruh positif secara signifikan terhadap kualitas laporan keuangan pemerintah daerah.

24 Desi Indriasari dan Ertambang Nahartyo, Pengaruh Kapasitas Sumberdaya Manusia, Pemanfaatan Teknologi Informasi, dan Pengendalian Intern Akuntansi terhadap Nilai Informasi Pelaporan Keuangan Pemerintah Daerah (Studi pada Pemerintah Kota Palembang dan Kabupaten Ogan Ilir), 2008.

25 Ibid., hlm. 3.

26 Hongjiang Xu, et al., Key Issues of Accounting Information Quality Management: Australian Case Studies, 2003.

27 Fariziah Choirunisah, Faktor-Faktor yang Mempengaruhi Kualitas Informasi Laporan Keuangan yang Dihasilkan Sistem Akuntansi Instansi (Studi pada Satuan Kerja di Wilayah Kerja KPPN Malang Tahun 2008), 2008.

28 Subadriyah, Analisis Hubungan Dukungan Pimpinan, Kualitas Sumber Daya Manusia dan Kualitas Sistem Akuntansi Keuangan Daerah dengan Kualitas Laporan Keuangan Pemerintah Daerah, Tesis tidak dipublikasikan, 2014, (Semarang: FEB Universitas Diponegoro).

\subsubsection{Efektivitas Auditor Internal Berpengaruh Positif terhadap Kualitas LKPD}

Hasil pengujian hipotesis menunjukkan bahwa hipotesis ke-3 efektivitas auditor internal berpengaruh positif terhadap kualitas LKPD ditolak. Efektivitas auditor internal berpengaruh positif tetapi tidak signifikan terhadap kualitas LKPD dengan koefisien jalur 0,229.

Berdasarkan jawaban responden, auditor internal yang melakukan pengawasan baik berupa audit, reviu, pemantauan dan evaluasi belum memiliki pengetahuan dan keahlian yang memadai dalam melaksanakan tugasnya. Nilai loading factor variabel efektivitas auditor internal berada dalam kisaran 0,866 sampai dengan 0,915, dimana indikator auditor internal yang melakukan pengawasan memiliki pengetahuan dan keahlian yang memadai dalam melaksanakan tugasnya menunjukkan loading factor sebesar 0,886. Sedangkan indikator audit internal berperan dalam menunjang pengendalian internal serta saran dan rekomendasi yang diberikan oleh auditor internal mudah dipahami dan dilaksanakan menunjukkan loading factor sebesar 0,899 dan 0,915.

Hasil penelitian ini tidak sejalan dengan salah satu dari asumsi dasar (fundamental assumptions of stewardship theory) yang menggambarkan bahwa para pimpinan tidak termotivasi oleh tujuan-tujuan individu tetapi lebih ditujukan pada sasaran utama untuk kepentingan organisasi sehingga steward (manajemen) bertindak sesuai keinginan principal. Gagalnya penelitian ini mendukung hipotesis ke-3 kemungkinan disebabkan karena belum memadainya pengetahuan dan keahlian auditor internal yang melakukan pengawasan dan reviu terhadap laporan keuangan.

Pengetahuan dan keahlian auditor internal yang masih belum memadai di lingkungan Pemerintah Kota Semarang tidak mempengaruhi kualitas LKPD yang disajikan. Hal ini ditunjukkan dengan jawaban responden atas kualitas LKPD yang sudah relatif baik dimana nilai rata-rata aktual kualitas LKPD sebesar 16,41 yang lebih tinggi dibandingkan dengan rata-rata teoritisnya sebesar 12,00 (Tabel 5).

Hasil penelitian ini sejalan dengan penelitian yang dilakukan oleh Nurdiono (2014) yang membuktikan bahwa efektivitas auditor internal tidak berpengaruh signifikan terhadap kualitas LKPD. ${ }^{29}$ Namun, hasil penelitian ini tidak sejalan dengan penelitian yang dilakukan oleh Haliah (2012) yang menyatakan bahwa kualitas auditor internal berpengaruh positif secara signifikan

29 Nurdiono, Op.Cit., hlm. 3. 
terhadap kualitas laporan keuangan pemerintah daerah. 30

\subsubsection{Kualitas Sistem Akuntansi Berpengaruh Positif terhadap Kualitas LKPD}

Hasil pengujian hipotesis menunjukkan bahwa hipotesis ke-4 kualitas sistem akuntansi berpengaruh positif terhadap kualitas LKPD diterima. Kualitas sistem akuntansi berpengaruh positif dan signifikan terhadap kualitas LKPD dengan koefisien jalur 0,386.

Berdasarkan jawaban responden, sistem akuntansi yang digunakan telah menunjukkan kualitas yang baik. Indikator aplikasi komputer atau sistem informasi pengelolaan keuangan daerah yang ada telah memudahkan SKPD dalam menyusun laporan keuangan, pengelolaan keuangan SKPD sudah menggunakan alat bantu (sistem aplikasi) atau sistem informasi pengelolaan keuangan daerah yang mempermudah dan mendukung proses pengolahan data keuangan yang baik dan aplikasi komputer atau sistem informasi pengelolaan keuangan daerah yang ada telah membantu tugas-tugas Bendahara menunjukkan loading factor sebesar 0,905 dan 0,916 . Sedangkan variabel aplikasi komputer atau sistem informasi pengelolaan keuangan daerah yang ada telah membantu tugas-tugas Pejabat Pelaksana Teknis Kegiatan (PPTK) menunjukkan loading factor sebesar 0,776. Nilai loading factor variabel kualitas sistem akuntansi berada dalam kisaran 0,776 sampai dengan 0,916.

Hasil penelitian ini sejalan dengan teori stewardship mengasumsikan bahwa kepentingan manajer dan principal adalah konvergensi, dimana keduanya mempunyai tujuan yang sama yaitu kepentingan organisasi. Dalam konteks penelitian ini, pemerintah daerah Kota Semarang telah membangun sistem yang berkualitas guna mewujudkan penyajian laporan keuangan yang berkualitas.

Laporan keuangan pemerintah daerah Kota Semarang telah memiliki kualitas yang baik. Hal ini dapat dilihat berdasarkan jawaban responden dimana nilai rata-rata aktual variabel kualitas LKPD sebesar 16,41 yang lebih tinggi dibandingkan dengan rata-rata teoritisnya sebesar 12,00 (Tabel 5).

Hasil penelitian ini mendukung berbagai penelitian terdahulu yang pernah dilakukan yaitu penelitian dari Xu et al. (2003) ${ }^{31}$, Widyaningsih, et al. $(2011)^{32}$ dan Subadriyah (2014) ${ }^{33}$ yang membuktikan bahwa sistem akuntansi yang berkualitas akan mendorong dihasilkannya laporan keuangan yang berkualitas.

\subsubsection{Penyelesaian Tindak Lanjut Temuan BPK Berpengaruh Positif terhadap Kualitas LKPD}

Hasil pengujian hipotesis menunjukkan bahwa hipotesis ke-5 penyelesaian tindak lanjut temuan BPK berpengaruh positif terhadap kualitas LKPD diterima. Penyelesaian tindak lanjut temuan BPK berpengaruh positif dan signifikan terhadap kualitas LKPD dengan koefisien jalur 0,274.

Berdasarkan jawaban responden, tindak lanjut temuan audit laporan keuangan atas hal-hal yang berkaitan dengan pengendalian intern telah dilakukan dengan baik. Indikator SKPD telah menindaklanjuti semua temuan audit laporan keuangan atas hal-hal yang berkaitan dengan pengendalian intern menunjukkan loading factor sebesar 0,964. Sedangkan indikator SKPD telah menindaklanjuti semua temuan audit laporan keuangan atas hal-hal yang berkaitan dengan kepatuhan terhadap ketentuan peraturan perundang-undangan menunjukkan loading factor sebesar 0,787 .

Hasil penelitian ini sejalan dengan teori stewardship dimana para pimpinan tidak termotivasi oleh tujuan-tujuan individu tetapi lebih ditujukan pada sasaran utama untuk kepentingan organisasi sehingga steward (manajemen) bertindak sesuai keinginan principal. Dalam hal ini manajemen pada pemerintah daerah Kota Semarang telah menindaklanjuti temuan dan rekomendasi yang disampaikan BPK guna memperbaiki pengelolaan keuangan dan penyajian laporan keuangan.

Laporan keuangan pemerintah daerah Kota Semarang telah memiliki kualitas yang baik. Hal ini dapat dilihat berdasarkan jawaban responden dimana nilai rata-rata aktual variabel kualitas LKPD sebesar 16,41 yang lebih tinggi dibandingkan dengan rata-rata teoritisnya sebesar 12,00 (Tabel 5).

Hasil penelitian ini sejalan dengan penelitian yang dilakukan oleh Silviana (2011) yang menyatakan bahwa komitmen kepala daerah untuk menindaklanjuti tindak lanjut hasil temuan BPK

31 Hongjiang Xu, et al., Op.Cit., hlm. 10.

32 Aristanti Widyaningsih, et al., Op.Cit., hlm. 3.

33 Subadriyah, Op.Cit., hlm. 10.
30 Haliah, Kualitas Informasi Laporan Keuangan Pemerintah Daerah dan Faktor-Faktor yang Mempengaruhinya, Disertasi tidak dipublikasikan, 2012, (Makassar: FEB Universitas Hasanuddin). 
berpengaruh positif terhadap kualitas LKPD. ${ }^{34}$ Namun, hasil penelitian ini tidak sejalan dengan penelitian yang dilakukan oleh Nurdiono (2014) yang membuktikan tindak lanjut temuan BPK tidak berpengaruh signifikan terhadap kualitas LKPD. ${ }^{35}$

\section{KESIMPULAN DAN SARAN}

\subsection{Kesimpulan}

Penelitian ini dilakukan berdasarkan kerangka pemikiran yang kemudian diadakan pengujian mengenai pengaruh komitmen manajemen, kompetensi sumber daya manusia, efektivitas auditor internal, kualitas sistem akuntansi dan penyelesaian tindak lanjut temuan BPK terhadap terhadap kualitas laporan keuangan pemerintah daerah. Rumusan masalah pada penelitian ini dijabarkan dalam 5 (lima) hipotesis.

Berdasarkan hasil penelitian, dari lima hipotesis sebanyak dua hipotesis diterima sedangkan tiga hipotesis lainnya ditolak. Hasil penelitian tersebut dapat menjawab rumusan masalah dan tujuan penelitian ini dimana dapat disimpulkan bahwa komitmen manajemen dan efektivitas auditor internal berpengaruh positif tapi tidak signifikan terhadap kualitas LKPD. Kompetensi sumber daya manusia berpengaruh negatif tetapi tidak signifikan terhadap kualitas LKPD. Sedangkan dua variable lainnya yaitu kualitas sistem akuntansi dan penyelesaian tindak lanjut temuan BPK memiliki pengaruh positif dan signifikan terhadap kualitas laporan keuangan pemerintah daerah.

Komitmen manajemen berpengaruh positif tapi tidak signifikan terhadap kualitas LKPD. Tidak signifikannya pengaruh komitmen manajemen terhadap kualitas LKPD kemungkinan disebabkan karena komitmen manajemen di lingkungan pemerintah Kota Semarang belum sepenuhnya optimal.

Kompetensi sumber daya manusia berpengaruh negatif tetapi tidak signifikan terhadap kualitas laporan keuangan pemerintah daerah. Pengaruh negatif tetapi tidak signifikan ini kemungkinan disebabkan karena kurangnya pengembangan kompetensi terhadap sumber daya manusia bidang pengelolaan keuangan dan penyajian laporan keuangan yang ada pada pemerintah Kota Semarang.

Efektivitas auditor internal berpengaruh positif tetapi tidak signifikan terhadap kualitas LKPD. Tidak signiifikannya pengaruh efektivitas auditor internal terhadap kualitas laporan keuangan pemerintah daerah kemungkinan disebabkan karena belum memadainya pengetahuan dan keahlian auditor internal yang melakukan pengawasan dan reviu terhadap laporan keuangan di lingkungan Pemerintah Kota Semarang.

Kualitas sistem akuntansi berpengaruh positif dan signifikan terhadap kualitas LKPD. Hasil ini menunjukkan bahwa semakin baik kualitas sistem akuntansi yang digunakan maka akan mendorong peningkatan kualitas LKPD. Sebaliknya apabila kualitas sistem akuntansi yang digunakan kurang baik maka akan menurunkan kualitas laporan keuangan yang disajikan. Sistem akuntansi yang digunakan di lingkungan Pemerintah Kota Semarang telah memudahkan SKPD dalam menyusun laporan keuangan serta mempermudah dan mendukung proses pengolahan data keuangan yang baik.

Penyelesaian tindak lanjut temuan BPK berpengaruh positif dan signifikan terhadap kualitas LKPD. Hasil ini menunjukan bahwa pemerintah daerah Kota Semarang telah menindaklanjuti dengan baik temuan dan rekomendasi yang disampaikan BPK guna memperbaiki pengelolaan keuangan dan penyajian laporan keuangan.

\subsection{Saran}

Berdasarkan hasil penelitian dan pembahasan dapat diketahui bahwa kualitas sistem akuntansi dan penyelesaian tindak lanjut temuan BPK berpengaruh positif dan signifikan terhadap kualitas laporan keuangan pemerintah daerah. Sedangkan variabel lain meliputi komitmen manajemen, kompetensi sumber daya manusia dan efektivitas auditor internal tidak signifikan mempengaruhi kualitas laporan keuangan pemerintah daerah.

Dalam hal ini menjadi penting bagi pemerintah daerah untuk membangun sistem akuntansi yang baik dan memudahkan pengguna dalam mengelola dan menyajikan laporan keuangan. Kesungguhan untuk menindaklanjuti temuan dan rekomendasi BPK oleh pimpinan entitas dan atau pihak yang berkompetensi melaksanakan rekomendasi hasil pemeriksaan BPK menjadi faktor penting berikutnya guna mendukung penyajian laporan keuangan yang berkualitas.

\footnotetext{
34 Silviana, Op.Cit., hlm. 9.

35 Nurdiono, Op.Cit., hlm. 3.
} 


\section{IMPLIKASI DAN KETERBATASAN}

\subsection{Implikasi}

Hasil penelitian ini mempunyai dua implikasi yang meliputi implikasi praktis terhadap pemerintah daerah Kota Semarang dan implikasi teoritis terhadap pengembangan ilmu pengetahuan khususnya bidang akuntansi pemerintahan. Implikasi praktis, hasil penelitian membuktikan bahwa kualitas sistem akuntansi dan penyelesaian tindak lanjut temuan BPK merupakan faktor yang berpengaruh signifikan terhadap kualitas LKPD.

Hal ini dimungkinkan karena semakin baik kualitas sistem akuntansi yang digunakan maka akan mendorong peningkatan kualitas LKPD. Sebaliknya apabila kualitas sistem akuntansi yang digunakan kurang baik maka akan menurunkan kualitas laporan keuangan yang disajikan. Kualitas sistem akuntansi merupakan salah satu faktor penting bagi organisasi pemerintahan untuk bisa mewujudkan pengelolaan keuangan yang baik serta menyajikan laporan keuangan yang berkualitas. Sistem akuntansi yang baik bisa menjadi filter terhadap penyimpangan dalam pengelolaan keuangan, serta meningkatkan kualitas laporan keuangan. Sistem akuntansi yang baik akan mendukung terwujudnya laporan keuangan yang sesuai dengan standar akuntansi, bahkan ketika laporan keuangan tersebut disusun oleh pegawai yang tidak/ belum memiliki keahlian yang memadai di bidang pengelolaan keuangan daerah maupun keahlian di bidang akuntansi.

Tindak lanjut rekomendasi BPK yang makin efektif akan mengurangi terjadinya temuan berulang serta meningkatkan kualitas pengelolaan dan tanggung jawab keuangan daerah. Kualitas sistem akuntansi yang baik didukung dengan komitmen untuk menindaklanjuti temuan dan rekomendasi BPK menjadi faktor penting yang mendukung kualitas LKPD yang disajikan.

Hasil ini diharapkan bisa menjadi acuan bagi pihak-pihak yang terkait dengan pemerintah daerah untuk memperhatikan pentingnya membangun/ menggunakan sistem akuntansi yang berkualitas dan komitmen untuk menindaklanjuti temuan dan rekomendasi BPK. Melalui kedua hal tersebut diharapkan penyajian laporan keuangan pemerintah daerah yang berkualitas dapat terwujud.

Implikasi teoritis terhadap pengembangan ilmu pengetahuan khususnya bidang akuntansi pemerintahan juga memberikan referensi tambahan yang sama bahwa kualitas sistem akuntansi dan penyelesaian tindak lanjut temuan BPK merupakan faktor yang berpengaruh terhadap kualitas LKPD. Hasil penelitian ini diharapkan akan berimplikasi untuk mendorong bagi adanya penelitian di bidang akuntansi pemerintahan dalam rangka menganalisis lebih lanjut mengenai faktor-faktor yang mempengaruhi kualitas laporan keuangan pemerintah daerah.

\subsection{Keterbatasan}

Penelitian ini tidak terlepas dari keterbatasan-keterbatasan yang diharapkan dapat diatasi pada penelitian selanjutnya. Berikut beberapa keterbatasan yang ada dan saran-saran bagi penelitian selanjutnya:

1. Penelitian ini hanya menggunakan metode kuesioner sehingga data dalam penelitian ini merupakan hasil dari instrumen yang berdasarkan pada persepsi responden. Oleh karena itu jika responden memberikan jawaban tidak sesuai kenyataan maka akan berpengaruh pada hasil penelitian. Diharapkan penelitian berikutnya menambahkan metode wawancara langsung dalam pengumpulan data, agar dapat mengurangi adanya kelemahan internal validity.

2. Obyek penelitian hanya meliputi satu pemerintah daerah yaitu pemerintah Kota Semarang. Oleh karena itu hasil penelitian ini kurang bisa digeneralisir. Penelitian selanjutnya disarankan agar dilakukan pada beberapa pemerintah daerah sehingga hasil penelitian lebih dapat digeneralisasi dan bisa menjadi perbandingan terkait faktor-faktor yang mempengaruhi kualitas laporan keuangan pemerintah daerah.

\section{DAFTAR PUSTAKA (REFERENCES)}

Akbar, R., Pilcher, R., \& Perrin, B. (2012). Performance Measurement in Indonesia: the Case of Local Goverment. Retrieve from Emerald Insight website: www.emeraldinsight.com.

Artley, W. (2001). The Performance Management Handbook Volume 3: Establisihing Accountability for Performance. USA: Performance-Based Management Special Interest Group (PBMSIG).

Badan Pemeriksa Keuangan RI. (2014). Ikhtisar Hasil Pemeriksaan Semester I Tahun 2014. Jakarta, September 2014

Badan Pemeriksa Keuangan RI. (2014). Ikhtisar Hasil Pemeriksaan Semester II Tahun 2014. Jakarta, Mei 2015.

Bansal, H.S., et al. (2004). A Three Component Model of Customer Commitment to Service Providers. Academy of Marketing Science, 32 (3). 
Bauwhede, H.V. (2001). What Factors Influence Financial Statement Quality a Frame and Some Empirical Evidence. Disampaikan pada The Euroconference on Financial Reporting and Regulatory Practices in Europe, Parlermo, Italy.

Cavalluzzo, K.S. \& Ittner, C.D. (2003). Implementing Performance Measurement Innovations: Evidence from Government. Retrieve from SSRN website: www.ssrn.com, hlm. 1-54.

Choirunisah, F. (2008). Faktor-Faktor yang Mempengaruhi Kualitas Informasi Laporan Keuangan yang Dihasilkan Sistem Akuntansi Instansi (Studi pada Satuan Kerja di Wilayah Kerja KPPN Malang Tahun 2008), Retrieve from google website www.google.com.

Donaldson, L \& Davis, J.H. (1991). Stewardship Theory or Agency Theory: CEO Governance and Shareholder Return. Australian Journal of Management, 1, June 1991, hlm. 49-65.

GAO. (2001). Managing For Results: Federal Managers' Views on Key Management Issues Vary Widely Across Agencies. MD: General Accounting Office, Gaithersburg, GA0-01592.

Governmental Accounting Standards Board (GASB). (1999). Concepts Statement No.1, Objectives of Financial Reporting.

Ghozali, I. \& Latan, H. (2015). Partial Least Square Konsep, Teknik dan Aplikasi Menggunakan Program SmartPLS 3.0, edisi 2, Semarang: Badan Penerbit Universitas Diponegoro.

Griffin, R.W. (2004). Manajemen, Edisi Ketujuh, Jilid 2, (Alih Bahasa, Gina Gania). Jakarta: Penerbit Erlangga.

Haliah. (2012), Kualitas Informasi Laporan Keuangan Pemerintah Daerah dan FaktorFaktor yang Mempengaruhinya. Disertasi, Tidak Dipublikasikan, FEB Universitas Hasanuddin.

Hall, J.A. (2004). Accounting Information Systems. South-Western: Thomson.

Hevesi, G.A. (2005). Standards for Internal Control in New York State Government. Retrieve from New York State Government website: www.osc.state.ny.us.

Hongjiang $\mathrm{X}_{._{2}}$ Jeretta H.N., Nord, G.D \& Lin, B. (2003) Key Issues of Accounting Information Quality Management: Australian Case Studies. Retrieve from Emerald Insight website: http://www.emeraldinsight.com.

Indriasari, D. \& Nahartyo, E. (2008). Pengaruh Kapasitas Sumberdaya Manusia,
Pemanfaatan Teknologi Informasi, dan Pengendalian Intern Akuntansi terhadap Nilai Informasi Pelaporan Keuangan Pemerintah Daerah (Studi pada Pemerintah Kota Palembang dan Kabupaten Ogan Ilir), Retrieve from Wordpress website: https://smartaccounting.files.wordpress.com.

Mardiasmo. (2006). Perwujudan Transparansi dan Akuntabilitas Publik Melalui Akuntansi Sektor Publik: Suatu Sarana Good Governance. Jurnal Akuntansi Pemerintah, Vol. 2 No. 1, Mei 2006, hlm. 1-17.

Mardiasmo. (2007). Otonomi dan Manajemen Keuangan Daerah, Yogyakarta: Penerbit Andi.

Meigs, W.B., Whittington, O.R \& Meigs, R.F. (1989). Principles of Auditing, Seventh Edition. USA: Richard D. Irwin, Inc.

Mulyadi. (2001). Sistem Akuntansi. Jakarta: Salemba Empat.

Mulyadi \& Kanaka Puradireja. (2003). Auditing. Jakarta: Salemba Empat.

Nurdiono. (2014). Analisis Hasil Audit Laporan Keuangan Pemerintah Daerah di Seluruh Indonesia. Disertasi, Tidak dipublikasikan. FEB UGM.

Nurkhamid, M. (2008). Implementasi Inovasi Sistem Pengukuran Kinerja Instansi Pemerintah. Jurnal Akuntansi Pemerintah, Vol. 3, No. 1.

Rezaee, Z. (2003). High-Quality Financial Reporting: The Six-Legged Stool. Strategic Finance; ABI/INFORM Research, Feb 2003.

Shields, M. (1995). An empirical analysis of firm's implementation experiences with activitybased costing. Journal of Management Accounting Research, 7, hlm. 1-28.

Silviana, (2011). Pengaruh Komitmen Kepala Daerah terhadap Kualitas Laporan Keuangan Pemerintah Daerah.

Steccolini, I. (2002). Local Government Annual Report: an Accountability Medium. EIASM Conference on Accounting and Auditing in Public Sector Reforms, Dublin, September 2002. Retrieve from website: http://www.cergas.info.

Subadriyah. (2014). Analisis Hubungan Dukungan Pimpinan, Kualitas Sumber Daya Manusia dan Kualitas Sistem Akuntansi Keuangan Daerah dengan Kualitas Laporan Keuangan Pemerintah Daerah. Tesis, Tidak Dipublikasikan, FEB Universitas Diponegoro. 
Widodo, J. (2001). Good Governance, Telaah dari Dimensi Akuntabilitas dan Kontrol Birokrasi Pada Era Desentralisasi dan Otonomi Daerah. Surabaya: Insan Cendekia.

Widyaningsih, A., Triantoro, A., \& Wiyantoro, L.S. (2011). Hubungan efektivitas SAKD dan pengendalian intern dengan kualitas akuntabilitas keuangan melalui kualitas informasi laporan keuangan sebagai variabel intervening, Simposium Nasional Akuntansi XIV, Aceh 2011.

Wilkinson, W.J., Michael, J.C., Raval, V., \& Wong-OnWing, B. (2000). Accounting Information Systems: Essential Concepts and Applications. Fourth Edition. John Wiley and Sons. Inc.

Yudianta, I.G.A. \& Erawati, N.M.A. (2012). Pengaruh Sumber Daya Manusia, Teknologi Informasi dan Pengendalian Intern Terhadap Kualitas Laporan Keuangan. Fakultas Ekonomi Universitas Udayana Bali.

Yuliani, dkk. (2010). Pengaruh Pemahaman Akuntansi, Pemanfaatan Sistem Informasi Akuntansi Keuangan Daerah dan Peran Internal Audit Terhadap Kualitas Laporan Keuangan Pemerintah Daerah (Studi Pada Pemerintah Kota Banda Aceh). Jurnal Telaah dan Riset Akuntansi, Vol. 3, No. 2, Juli 2010, hlm. 206-220. 